\title{
Samskipti fagfjárfesta við félög sem peir eru hluthafar í
}

\author{
Pröstur Olaf Sigurjónsson og J. Bjarni Magnússon ${ }^{1}$
}

\begin{abstract}
Ágrip
Miklar breytingar hafa orðið á eignarhaldi skráðra félaga á íslenskum hlutabréfamarkaði síðasta áratug. Á pví tímabili hafa fagfjárfestar orðið fyrirferðarmiklir á markaðnum. Pessi rannsókn varpar ljósi á pað með hvaða hætti íslenskir fagfjárfestar eiga í samskiptum við skráð félög par sem peir eru hluthafar. Enn fremur hvort og hvernig peir nota eignarhald sitt til pess að hafa áhrif á starfsemi viðkomandi félaga, pá sérstaklega stjórnarhætti. Helstu niðurstöður eru pær að samskipti íslenskra fagfjárfesta við pau félög sem fjárfest er í á sér stað bakvið tjöldin með fundum og óformlegum samskiptum. Рað gerist jafnframt með pví að vinna með eða á móti tillögum annarra hluthafa og kjósa með eða gegn peim á hluthafafundum. Petta er í samræmi við pað sem gerist í nágrannalöndum Íslands nema hvað gagnsæi er par meira í samskiptum en á Íslandi.
\end{abstract}

\section{Abstract}

A significant change in ownership of listed Icelandic companies has taken place over the past decade or so. The majority of the ownership is in the hands of institutional investors. The aim of this research is to improve understanding of how Icelandic institutional investors interact with companies in which they are shareholders and use their ownership to influence those companies, especially corporate governance. The main findings are that investment stewardship by Icelandic institutional shareholders happens behind the scenes with meetings and informal communication. It does also happen with public dissent of shareholder proposals and/or by voting for or against proposals at shareholder meetings. These findings are in line with how investment stewardship is in neighbouring countries, with the exception that transparency outside of Iceland is a more meaningful part of the stewardship process.

\section{JEL flokkun: G30; G32}

Lykilorð: Stjórnarhættir fyrirtækja, Ísland, fagfjárfestar, lífeyrissjóðir, hluthafastefna.

Keywords: Corporate governance, Iceland, institutional investors, pension funds, investment stewardship.

1 Pröstur Olaf Sigurjónsson er lektor við viðskiptafræðideild Háskóla Íslands. Netfang: olaf@ hi.is. Bjarni Magnússon er sérfræðingur í fjárhagslegu eftirliti hjá Fjármálaeftirlitinu. Netfang: bjarnim@gmail.com.

This work is licensed under a Creative Commons Attribution 4.0 License.

DOI: https://doi.org/10.24122/tve.a.2019.16.2.6

(C) Tímarit um viðskipti og efnahagsmál 


\section{Inngangur}

Stjórnarhættir hafa verið mikilvægir allt frá pví að félög hófu að afla fjármagns til starfsemi sinnar (Thomsen, 2019). Fjárfestum, sem geta verið fjármagnseigendur af ólíku tagi, er umhugað um hvernig félög sem peir fjárfesta í fara með pað fjármagn (OECD, 2015). Stjórnarhættir hafa verið skilgreindir með margvíslegum hætti, en helst er horft til trausts sem ríkja parf milli fjárfesta og félaga sem fjárfest er í (La Porta o.fl., 2000). Miklar breytingar urðu á eignarhaldi á íslenskum hlutabréfamarkaði í kjölfar efnahagshrunsins árið 2008 pegar markaðsverðmæti skráðra hlutabréfa hvarf við fall priggja banka (Ásta Dís Óladóttir, Friðrik Árni Friðriksson, Gylfi Magnússon og Valur Práinsson, 2017). Fyrir fjármálahrunið einkenndist eignarhaldið af mjög virkum fjárfestum með skuldsettar stöður, en eftir раð er sampjöppun eignarhalds ríkjandi, par sem fagfjárfestar eiga meira en helming hlutafjár félaga í kauphöll og eru lífeyrissjóðir par fyrirferðarmestir (Gylfi Magnússon, 2016; Gunnar Baldvinsson, Áslaug Árnadóttir og Eggert Benedikt Guðmundsson, 2018). Í ljósi pessa breytta eignarhalds er áhugavert viðfangsefni að rannsaka hvað einkennir samskipti fagfjárfesta við félög par sem peir eru hluthafar. Enn fremur hvort og hvernig peir nota eignarhald sitt til pess að hafa áhrif á starfsemi viðkomandi félaga, pá sérstaklega stjórnarhætti.

Gjaldeyrishöft voru kynnt í nóvember 2008 og hafa íslenskir lífeyrissjóðir síðan átt umtalsverðar stöður í skráðum félögum á íslenskum hlutabréfamarkaði. Í lok árs 2008 náðu erlendar eignir lífeyrissjóðanna 30\% heildareigna peirra, en voru komnar niður í 25\% í lok árs 2017 og eru í lok október 2019 komnar í 29,44\% (Seðlabanki Íslands, 2019). Eignir peirra sem hlutfall af vergri landsfamleiðslu (GDP) hafa verið háar í samanburði við OECD lönd og töldu 151\% af landsframleiðslu í lok árs 2018 (Seðlabanki Íslands, 2019). Skortur á fjárfestingartækifærum hefur beint lífeyrissjóðunum í átt til íslenska hlutabréfamarkaðarins par sem peir hafa verið ráðandi undanfarin ár (Gunnar Baldvinsson, Áslaug Árnadóttir og Eggert Benedikt Guðmundsson, 2018).

Sú próun að einstaklingum hefur fækkað sem fjárfestum á hlutabréfamarkaði hefur átt sér stað á Íslandi sem og annars staðar en fagfjárfestar og sjóðir hafa vaxið sem fjárfestar á móti. Fagfjárfestar eru í dag stærstu eigendur skráðra hlutabréfa í vestrænum ríkjum. Рað er pó sjaldgæft að slíkir sjóðir eigi hver ráđandi hlut í félagi. peir eru pó áhrifaríkir í gegnum eignarhluti sína og sérstaklega á petta við um Bandaríkin (Fitcher o.fl., 2017). Pessar sviptingar á eignarhaldi hafa bæði jákvæð og neikvæð áhrif. Fjárfestar sem horfa helst til vísitölusjóða hafa oft meiri tilhneigingu til pess að taka fjárfestingarákvörðun út frá langtíma sjónarmiði (Larry, 2017). Hins vegar eru minnihluta fjárfestar stundum í aðstöðu til pess að hafa áhrif umfram fjárfestingar sínar pví fagfjárfestar hafa tilhneigingu til pess að vera óvirkir eigendur (Schleifer og Vishny, 1986). Hugleiðingarnar hér á undan vekja upp rannsóknarspurningu sem pessi rannsókn leitast við að finna svar við; hvernig er samskiptum fagfjárfesta við félög sem peir eru hluthafar í háttað?

Greinin er skipulögð pannig: fyrst er gefið fræðilegt yfirlit, pá er fjárfestaumhverfið á Íslandi kynnt með sérstaka áherslu á lífeyrissjóði og önnur eignastýringarfyrirtæki; erlend umfjöllun um efnið er jafnframt að finna í peim kafla greinarinnar. Pá er aðferðarfræði rannsóknarinnar kynnt og niðurstöður fylgja í kjölfarið. Að endingu er umræða og lokaorð.

\section{Fræðileg umfjöllun}

\subsection{Stórnarhættir}

Pegar eigendur félags ráða stjórnendur til pess að reka félagið í sínu umboði eru peir umjóðendur en stjórnendurnir umboðsmenn. Stjórnendur eru enn fremur fjárvörsluaðilar og eru fjárhaldsmenn gagnvart eigendum (Carlson, 2009). Hagsmunaárekstrar pessara tveggja aðila pekkjast og er hlutverk stjórnarhátta að skapa umgjörð fyrir bæði samstarfið og skipulag félagsins sem í hlut á. Vandinn getur birst með tvennum hætti; annars vegar að eigendur og stjórnendur kunna að hafa ólík markmið og hins vegar kunna ólíkar upp- 
lýsingar um starfsemina og störf stjórnenda að skapa ójafnræði milli eigenda og stjórnenda. Petta hefur verið kallað umboðsvandi (Gilian og Starks, 2003).

Stjórnarhættir skýra pví tengsl og samskipti milli eigenda félags, stjórnar pess, stjórnenda og annarra hagaðila. Stjórnarhættir búa til pað skipulag sem félag starfar eftir og setur pví markmið og ákvarðar með hvaða hætti eigi að ná peim ásamt pví að tilgreina hvernig árangur er metinn (OECD, 2015). Frá sjónarhorni eigenda eru stjórnarhættir ferli eftirlits með starfsemi félags og stjórnendum peirra, pannig sjónarmiðum eigenda sé fylgt (ICSA The Governance Institute, 2017).

\subsection{Stjórnarhættir og hluthafastefna}

Eignarhald fyrirtækja er ólíkt og stjórnarhættir taka mið af pví (Sjöstrand o.fl., 2016; Pröstur Olaf Sigurjónsson, Thomas Poulsen og Guðrún Erla Jónsdóttir, 2019). Fagfjárfestar eru ein tegund eigenda og miðar pessi rannsókn meðal annars að pví að skilja hvers kyns eigendur peir eru á Íslandi og hvaða stjórnarhættir einkenna starf peirra. Hirschman (1970) telur að fjárfestar hafi tvær leiðir til pess bregðast við óánægju með fjárfestingu. Önnur leiðin er að virkja samtal við stjórnendur og hin leiðin er að selja eign sína. Pá pekkist millileiðin, að fjárfestir hótar að selja eign sína. Hefur sú leið sannað sig sem tæki til pess að hafa áhrif á stjórnendur skráðra félaga (Bharath o.fl., 2013). Hluthafastefna er pað pegar fjárfestir hefur ákveðið með hvaða hætti hann ætlar að hafa áhrif á fjárfestingu sína (McCahery o.fl., 2016). Áhrif fjárfesta í gegnum samtal eru; kosningar á hluthafafundum, samkomulag fjárfesta (eigenda / hluthafa), samskipti við fulltrúa félags (stjórnarmenn, stjórnendur og aðra haghafa) og málaferli (Van der Elst og Aslan, 2009). Sumir telja að hótun um sölu eignarhluta sé ein áhrifaríkasta leiðin til pess að hafa áhrif (McCahery o.fl., 2016; Edmans, 2009).

Í breskum leiðbeiningum FRC stofnunarinnar (Financial Reporting Council) um meðferð á eignarhaldi félaga í umboði annarra pá skulu fjárfestar setja sér hluthafastefnu og er talað um að hlutverk hennar sé að styðja við góða stjórnarhætti. Í uppfærslu leiðbeininganna sem gilda frá 1. janúar 2020 er gengið lengra en í fyrri útgáfum og fjárfestum sem vilja starfa eftir leiðbeiningunum gert að skila inn skýrslu um samskipti sín við félög par sem peir eru hluthafar (Financial Reporting Council, 2020). Talað er um að hluthafastefna hafi pað hlutverk að styðja við langtíma árangur í rekstri félags og með peim hætti njóti fjárfestar ávinnings. Hluthafastefna sé pó ekki aðeins um pað að eiga samtal eða kjósa með fótunum, heldur sé hlutverk hluthafastefnu að hafa skoðun og áhrif á stefnumótun, áhættumat, fjármagnsskipan og stjórnarhætti (Financial Reporting Council, 2012). Leiðbeiningarnar voru endurskrifaðar í kjölfar fjármálaáfallsins árið 2008, par sem ljóst pótti að eftirlitshlutverk fjárfesta hafði ekki verið skýrt (Walker, 2009; Goergen o.fl., 2008). Rannsókn McCharey o.fl. (2016) varpaði ljósi á að samskipti fjárfesta við félag sem peir eru hluthafar í færu að mestu fram á bakvið tjöldin. Bein samskipti eru við forstjóra og stjórnarformann (oftast án vitneskju annarra stjórnenda) og pau samskipti eru ekki opinber. Enn fremur að fjárfestar sem skilgreina sig sem langtíma fjárfesta hafa meiri samskipti við forstjóra og stjórnarformann heldur en aðrir (Bebchuk o.fl., 2014). Fjárfestar með stærri eignarhluti skipta sér meira af starfsemi félaga en peir sem smærri hluti eiga (Huddart, 1993). Fagfjárfestar virðast pó ekki eiga mikil afskipti af daglegum rekstri peirra félaga sem peir fjárfesta í (Grossman og Hart, 1980; Shcleifer og Vishny, 1986). Flestir fjárfestar hafa ekki mannafla til pess að sinna stefnumarkandi og virku eftirlitshlutverki (Isaksson og Celik, 2013). Afskipti eru fyrst og fremst í kjölfar tilkynninga eða atburða í rekstri félags, en ekki fyrirfram ákveðin inngrip eða afskipti (Giannetti og Laeven, 2009).

Árin eftir 2008 hafa einkennst af sterkari aðkomu fagfjárfesta að skráðum félögum á meðan einstaklingum sem fjárfestum hefur fækkað (Wong, 2015). Petta hefur leitt til aukinna krafna um gagnsæi og upplýsingagjöf fagfjárfesta. OECD hefur í pessu ljósi lagt aukna áherslu á að fagfjárfestar horfi til góðra stjórnarhátta (OECD Principles of Corporate Governance, 2015). Ekki eru allir fjárfestar í aðstöðu til pess að hafa bein áhrif á félög 
og á pað til að mynda við um pá sem fjárfesta í vísitölusjóðum, sjóðum í virkri stýringu og annarri tegund fjárfestinga par sem umboðsaðili sinnir fjárfestingunni. Peir aðilar geta pó komið sjónarmiðum sínum á framfæri og rætt við stjórnendur sjóðanna (Fichtner o.fl., 2017).

Virkni fjárfesta má meta með pví að greina hversu stórt hlutfall peirra nýtir kosningarétt sinn á hluthafafundum. Rannsókn í nokkrum OECD löndum leiðir í ljós að virkustu fjárfesta er að finna í Bandaríkjunum og Bretlandi. Í Bandaríkjunum nýta $80 \%$ fjárfesta rétt sinn til kosninga og 70\% í Bretlandi (Hewitt, 2011). Pessi hlutföll eru hærri en sést hafa í Vestur Evrópu, en ástæðan kann að vera sú að í Bretlandi og Bandaríkjunum er hefð fyrir pví að fagfjárfestar framselji rétt sinn til kosninga til priðja aðila (Isaksson og Celik, 2013; SEC, 2010). Meðaltal hvað nýtingu kosningaréttar Vestur Evrópu á árinu 2015 var 67,2\%. Breytileikinn er nokkur par sem Danmörk sýnir lægsta hlutfallið $(48,9 \%)$ og Luxemburg pað hæsta (73,8\%) (Institutional Shareholder Services, 2015).

\subsection{Fagfjárfestar á Íslandi}

Fjárfestum á Íslandi má skipta í prennt samkvæmt Arion banka; fagfjárfestar, einkafjárfestar og fjárfestingarfélög (Ásdís Kristjánsdóttir, 2013). Í kjölfar afnáms fjármálahafta árið 2017 jukust fjárfestingar erlendra aðila í íslenskum félögum og má pví líta til peirra sem fjórðu tegund fjárfesta á Íslandi (Magnús Halldórsson, 2017). Nasdaq styðst við nákvæmari greiningu á fjárfestum eins og mynd 1 frá FME (2019) sýnir en hún varpar einnig ljósi á ólíkt umfang fjárfestinga fjárfesta í skráđum og óskráðum hlutabréfum. Lífeyrissjóðir eru lang stærstu fjárfestarnir á Íslandi með ríflega 4.200 milljarða ISK í stýringu í lok árs 2018 (Seðlabanki Îslands, 2019). Prír peirra stærstu eru með um helming pessara eigna í stýringu (Fjármálaeftirlitið, 2017a, 2017b). Skipulag peirra og lífeyrissjóðakerfisins byggir á lögum frá 1997 (lög nr. 129/1997) en uppruni pess nær aftur til ársins 1969 pegar yfirvöld og aðilar vinnumarkaðarins náðu samkomulagi um skyldu til greiðslna í lífeyrissjóði (Már Guðmundsson, 2000). Lögin tiltaka kröfur á herðar lífeyrissjóða um að peir setji sér fjárfestingarstefnu, áhættustefnu, séu skynsamir í fjárfestingum en takmarkanir eru jafnframt á fjárfestingar eftir eignaflokkum (Ragnhildur Helgadóttir, 2013; Már Guðmundsson, 2000). Hagfræðistofnun Háskóla Íslands skilaði skýrslu um mikilvægi íslensku lífeyrissjóðanna fyrir íslenskt efnahagslíf. Spáði hún að heildareignir lífeyrissjóðanna myndu vaxa frá 172\% af vergri landsframleiðslu árið 2015 til 200\% árið 2046. Einnig að á peim tíma muni peir eiga $40 \%$ af öllum hlutabréfum og skuldabréfum skráðra félaga á Íslandi (Sigurður Jóhannesson, 2017).

Pað eru samkvæmt Fjármálaeftirlitinu (2017a) tíu starfandi eignastýringarfyrirtæki á Íslandi og hafa pau um 830 milljarða ISK í stýringu í lok árs 2017. Miklar sveiflur hafa verið á stærð fjárfestinga sem skýrist af fjármálahruninu árið 2008. Fyrir hrunið voru heildareignir um 700 milljarðar ISK en fóru niður undir 200 milljarða ISK í kjölfar pess. Um áratug síðar hafa pær náð rúmlega fyrri stærð. Stærstu eignarstýringarfyrirtækin eru Stefnir hf, Íslandssjóðir hf og Landsbréf hf. Eignarhald peirra er í premur viðskiptabönkum landsins; Arion banka, Íslandsbanka og Landsbanka. Pjrú önnur fyrirtæki eru með yfir 100 milljarða í stýringu; Kvika banki og Gamma sem er nú í eigu Kviku banka og svo Íslensk verðbréf hf. 


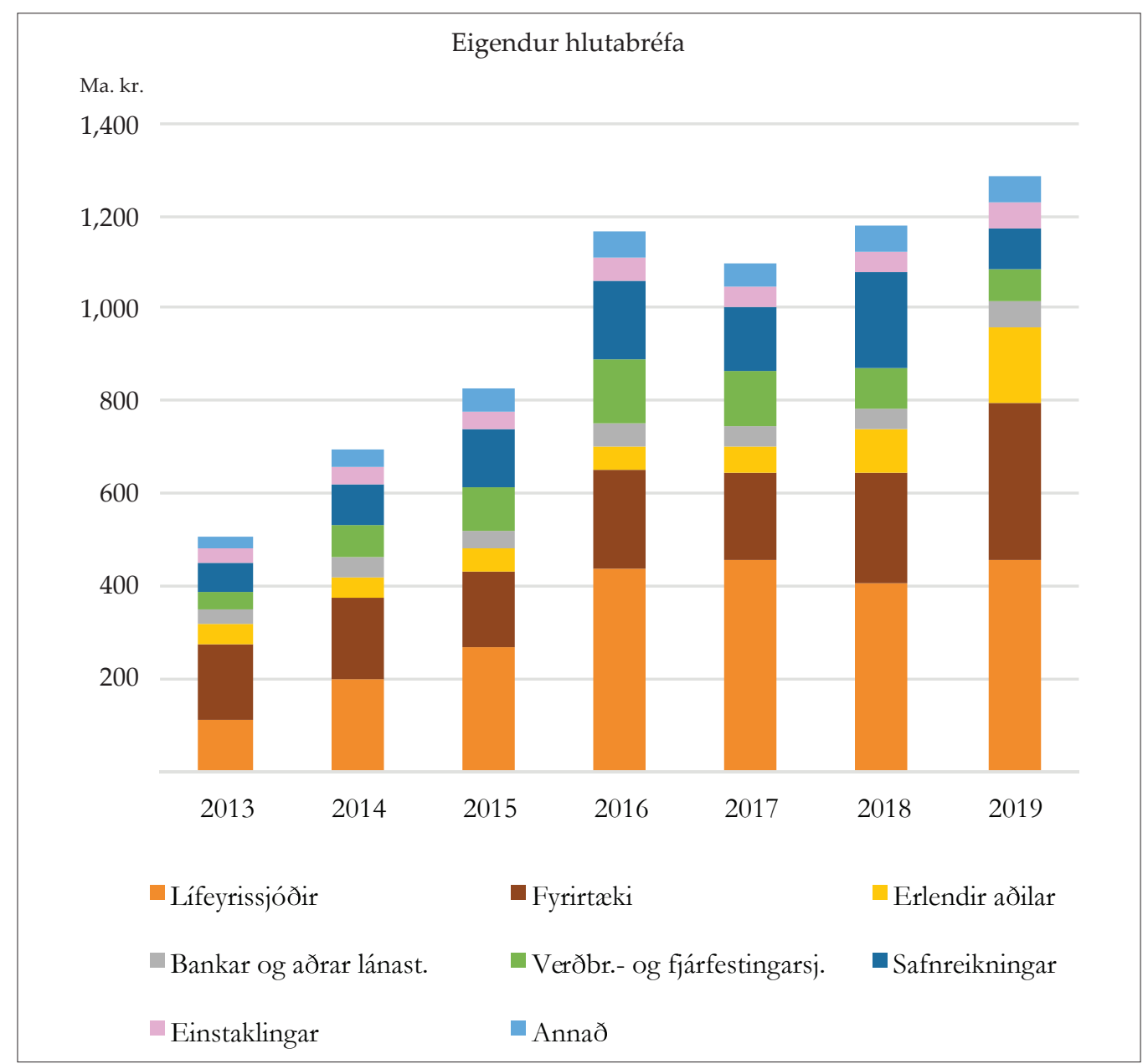

Mynd 1. Yfirlit yfir eigendur skráðra og óskráðra hlutabréfa (Nasdaq, 2019)

\subsection{Fjármálamarkaður á Íslandi}

Saga íslensks fjármálamarkaðar er ekki löng. Seinustu tveir áratugir síðustu aldar einkenndust af örum breytingum par sem losun hafta og einkavæðing var í fyrirrúmi. Kauphöll Íslands var stofnuð árið 1985 og pá undir nafninu Verðbréfaping Íslands (Gylfi Magnússon, 2007). Á pessum tíma var bankakerfið nánast að öllu leyti í eigu ríkisins. Lög og reglur tóku breytingum á pessum tíma, til að mynda um minnihlutavernd hluthafa sem voru við upphaf íslensks verðbréfamarkaðar vanpróaðar miðað við í dag (Gylfi Magnússon, 2007). Рað var ekki fyrr en árið 1995 að hugtakið hluthafastefna er fyrst nefnt og pá í Frjálsri verslun (Jón Hauksson, 1995). Vöxtur verðbréfamarkaðarins var ævintýralegur árin 2003-2007, pegar ríkisbankarnir höfðu verið einkavæddir, en purrkaðist nánast út í fjármálahruninu 2008 (Páll Hreinsson, Tryggvi Gunnarsson og Sigríður Benediktsdottir, 2010). Krafa um að íslenskir lífeyrissjóðir hefðu skýra stefnu í fjárfestingum og meðhöndlun eigna kom fram fljótlega eftir einkavæðingarferli fjármálakerfisins. Páverandi formaður Samfylkingarinnar hvatti lífeyrissjóði til að setja sér mjög varkára hluthafastefnu og skýra hvaða áherslur skyldu vera fyrir eignarhlutum (Lífeyrissjóðir sýni félagslega ábyrgð, 2006). Í kjölfarið innleiddu tveir lífeyrissjóðir hluthafastefnu byggða á PRI stöðlum Sameinuðu pjóðanna (Sunna Ósk Logadóttir, 2007).

Í kjölfar fjármálahrunsins var gagnrýnt hvernig fagfjárfestar sem lífeyrissjóðir hefðu haldið á fjárfestingum sínum. Alpýðusamband Íslands (ASÍ) fór fram á að lífeyrissjóðir myndu setja sér hluthafastefnu og enn fremur gefa út siðareglur (ASÍ, 2009). ASÍ fór enn fremur fram á að sjóðirnir myndu vera virkari fjárfestar, hafa skoðun á stjórnarháttum, skýra sýn til starfskjarastefna félaga sem peir fjárfesta í og hvernig staðið er að vali á stjórn- 
armönnum (ASÍ, 2013). Útgáfa rannsóknarskýrslu um starfsemi lífeyrissjóðanna árið 2012 ýtti mjög á um að lífeyrissjóðir settu sér hluthafastefnu par sem góðir stjórnarhættir yrðu í fyrirrúmi (Hrafn Bragason, Héðinn Eyjólfsson og Guðmundur Heiðar Frímannsson, 2012).

Lífeyrissjóðir hver á fætur öðrum kynntu í kjölfarið hluthafastefnu eða uppfærðu pær sem voru fyrirliggjandi. Gildi lífeyrissjóður uppfærði sína stefnu árið 2015 og hnykkti á hlutverki sínu sem virkur fjárfestir. Meiri áhersla var lögð á samskipti við stjórnir peirra félaga sem sjóðurinn fjárfesti í og virka pátttöku á hluthafafundum (Stefán Árni Pálsson, 2015; Gildi lífeyrissjóður, 2015). Petta er dæmigert fyrir pað skref sem íslenskir lífeyrissjóðir tóku. Á svipuðum tíma fóru erlendir fjárfestar að auka eignir sínar á Íslandi og höfðu sumir peirra áhrif á hver próun hluthafastefnu varð. Eaton Vance Management sjóðurinn, sem er hvað fyrirferðarmestur erlendra sjóða á Íslandi, sendi öllum skráðum íslenskum félögum, sem sjóðurinn átti hluti í, bréf í mars 2018 par sem hvatt var til notkunar tilnefningarnefnda við val á stjórnarmönnum. Ljóst má vera að fjárfestar hafa áhrif pegar peir beita sér, pó ekki sé nema með öðrum hætti en að kynna tilmæli, en flest íslensku félögin höfðu innleitt tilnefningarnefndir ári síðar (Morgunblaðið, 2018).

\subsection{Próun utan Íslands}

Íslenskur fjármálamarkaður próaðist síðar en í nágrannalöndunum og pað sama á við um tilkomu hluthafastefna. Sum lönd hafa tekið upp leiðbeiningar um gerð hluthafastefnu. Í maí 2017 sampykkti Evrópusambandið tilskipun (2007/36/EC) sem miðar pví að ýta undir langtíma sjónarmið í fjárfestingum. Hvatinn til að innleiða pessa tilskipun var gagnrýni á skammtíma sjónarmið í rekstri félaga á árunum fyrir 2008. Markmið er að stuðla að tilvist félaga til lengri tíma. Megin innihald slíkrar stefnu skal vera eftirfarandi:

- Starfskjarastefna á að vera fyrir hendi og skal hún taka fyrst og fremst til kjara stjórnarmanna og stjórnenda og stuðla að langtíma hagsmunum félags.

- Gagnsæi á að ríkja um eignarhald á félögum í öllum tilfellum.

- Félög skulu auðvelda hluthöfum að nýta kosningarétt sinn.

- Fagfjárfestar skulu gera grein fyrir pví með hvaða hætti peir hyggjast starfa sem fjárfestar. Hluthafastefna skal vera opinber og ef slíka stefnu er ekki að finna, skal gera grein fyrir pví hvers vegna svo sé. Slík stefna skal skýra hvernig fjárfestir hyggst meðhöndla mögulega hagsmunaárekstra.

Tilskipunin tók gildi pann 10. júní 2019 og líklegt er talið að hún verði innleidd á Íslandi par sem fyrri tilskipun er pegar í gildi („Directive (EU) 2017/828 - EFTA“, 2017). Leiðbeiningar til fjárfesta hvað hluthafastefnu varðar hafa verið kynntar í átta löndum. Pær eru valfrjálsar en tvö lönd hafa „,comply or explain“ klásúlu með leiðbeiningunum (OECD, 2017). Tvær eru ítarlegastar en раð eru pær bresku (Financial Reporting Council, 2012) og pær hollensku (Institutional investors establish the first edition of a Dutch Stewardship Code, 2017). Leiðbeiningarnar eiga að ýta undir langtíma hugsun fjárfesta par sem áhersla er lögð á að hlutverk fjárfesta snúist ekki aðeins um kosningar á hluthafafundum, heldur pað að veita aðhald í formi eftirlits sem og að eiga samtal um stefnumótun, áhættu og stjórnarhætti. Eitt megin markmið leiðbeininganna er að hvetja til samtals milli félaga og fjárfesta sem pykir draga úr líkum á mikilli áhættutöku (Financial Reporting Council, 2012).

Mjög stórir fjárfestar eins og Blackrock og Vanguard hafa haft mikil áhrif á próun hluthafastefna. Pessi félög hafa verið áfram um skýrari reglur og leiðbeiningar um vandaða starfshætti fjárfesta (ESG: Sharing stewardship, 2018). Blackrock, stærsta eignastýringarfyrirtæki í heimi, segist verja og auka virði viðskiptavina sinna með pví að eiga í beinu samtali við félögin sem fjárfest er í. Blackrock kýs á meira en 15.000 hluthafafundum árlega um yfir 130.000 tillögur á slíkum fundum. ESG hugtakið er orðið mjög fyrirferðarmikið hjá Blackrock, en pað tekur yfir umhverfispætti, samfélagspætti og stjórnarhætti 
félaga (e. environmental, social, governance). Árlega skrifar forstjóri Blackrock opinbert bréf par sem áhersla á stjórnarhætti er fyrirferðamest en bréfið á að vera leiðbeinandi fyrir pau félög sem fjárfest er í (Fink, 2017). Enn fremur gefur Blackrock út skýrslur og minnisblöð um einstaka pætti í starfsemi peirra félaga sem peir fjárfesta í, sé ástæða til slíks (Guidelines, reports and position papers, 2018). Pess ber pó að geta að sjóðastjórnunarfyrirtæki, par með talið Blackrock, hafa verið gagnrýnd fyrir að fjárfesta í fyrirtækjum sem standa sig illa á páttum ESG, sér í lagi í umhverfismálum (The American Proposect, 2019). Nordea er stærsta eignastýringarfyrirtæki á Norðurlöndunum, með yfir 360 milljarða USD í stýringu (Schwartzkopff, 2017). Рað hefur síðan 2014 verið opið um stuðning sinn við góða stjórnarhætti og gagnsæi í allri upplýsingagjöf. Pað birtir ávallt hvernig kosið var á hluthafafundum og gerir opinbert pegar pað er á öndverðum meiði við hugmyndir eða tillögur stjórnenda. Nordea styðst við leiðbeiningar OECD um góða stjórnarhætti pegar pað á í samstarfi við félög sem pað er hluthafi í.

\section{3 Аðferð}

Rannsóknaraðferðin felst í tveimur eigindlegum nálgunum; annars vegar er viðtölum beitt og hins vegar efnisgreiningu (e. content analysis), en efnisgreining er leið til pess að auka skilning á hegðun hópa eins og fjárfesta, með hvaða hætti peir starfa og hvaða aðferðir peir hafa próað (Bell, 2014). Viðtöl eru tekin við úrtak einstaklinga sem starfa hjá fagfjárfestum og við stjórnarmenn í skráðum félögum, með pað að markmiði að fá pann hluta upplýsinga upp á yfirborðið sem hefur að gera með óformlegan hluta starfsemi fagfjárfesta. Efnisgreiningin byggir á öflun gagna um hvort, hvenær og hvernig fagfjárfestar sinna hlutverki sínu sem fjárfestar samkvæmt opinberum gögnum.

\subsection{Viðtöl}

Hálf stöðluðum viðtölum var beitt par sem pau voru talin pjóna tilgangi rannsóknarinnar fyrir рað hversu sveigjanlegt pað form viðtalstækni er. Rannsakendur höfðu viðtalsramma og opnar spurningar til að styðjast við í viðtölunum, en sú nálgun auðveldar greiningar viðtalsefnisins (Bourgeault, Dingwall og Vries, 2010).

Til að ná sem bestum skilningi á viðfangsefnið var ákveðið að ræða bæði við úrtak fagfjárfesta og stjórnendur skráðra félaga. Fulltrúar fagfjárfesta sem rætt var við voru forstjórar (eða framkvæmdastjórar, eftir pví hvaða starfstitill er notaður). Pá var rætt við forstjóra og formenn stjórna skráðra félaga. Petta var gert til pess að fá báðar hliðar upplifunar af starfsemi fjárfesta. Sendar voru út 24 beiðnir um viðtöl (15 til skráðra félaga og 9 til lífeyrissjóða) og voru á endanum átta viðtöl tekin. Fjöldi viðmælanda frá fagfjárfestum var fjórir og fjórir frá skráðum félögum. Viðtölin fóru fram á tímabilinu nóvember 2017 apríl 2018. Trúnaðar er gætt með nafnleysi viðmælenda.

Viðtölin náðu yfir pá fjárfesta sem höfðu skráða hluthafastefnu. Einnig var haft samband við fulltrúa skráðra félaga sem voru oftast nær stjórnarformenn peirra. Haft var fyrst samband við væntanlega viðmælendur í gegnum tölvupóst með kynningarbréfi, par sem markmið rannsóknarinnar var kynnt og framkvæmd hennar. Viðtölin fóru pannig fram að fyrst var viðtalsramminn kynntur og með hvaða hætti rannsakendur hyggðust greina viðtölin. Í öllum viðtölunum var opinna spurninga spurt og peim fylgt eftir með öðrum spurningum. Öll viðtölin nema eitt fóru fram á starfsstöðvum hvers viðmælanda, nema eitt viðtal fór fram um síma. Stuðst var við viðtalsramma frá DiCicco-Bloom og Crabtree (2006) og McCahery, Starks, og Sautner (2016). Viðtölin voru kóðuð eftir pemum viðtalsrammans (sem er að finna hér á eftir), í sitthvoru lagi af höfundum til að tryggja samræmi. Niðurstöðurnar varpa ljósi á með hvaða hætti fjárfestar eiga samskipti við félög sem peir fjárfesta í. Mögulegar takmarkanir rannsóknarinnar eru pær að peir sem voru reiðbúnir til að taka pátt í rannsókninni gætu haft meiri áhuga á málefninu en peir sem ekki vildu taka pátt. 


\subsection{Greining fyrirliggjandi gagna}

Fréttveita NASDAQ OMX kauphallarinnar geymir mikið safn efnis um starfsemi skráðra félaga. Fréttum var safnað um öll félög sem höfðu skráð hlutabréf einhvern tímann á síðustu 15 árum en ekki eru mörg peirra með sögu allt tímabilið. Fréttum var safnað sem höfðu að gera með tilkynningar félaganna sjálfra til kauphallar, eins og um afkomu, ársuppgjör, viðskipti tengdra aðila og hluthafafundi. Upplýsingar um hluthafafundi fela í sér meðal annars dagskrá funda, tillögur sem lagðar eru fyrir hluthafa og fundargerðir. Horft var til pess að á seinustu 15 árum hefur íslenska hagkerfið tekið sveiflum.

Fjöldi skráðra tillagna fjárfesta (oft sem viðbragð við frétt) vegna skráðra félaga í kauphöll NASDAQ OMX Iceland voru 51 í 43 tilfellum. Árið 2018 eru flestar tillögur skráðar eða 19. Skoðaðar voru fréttir sem birtust frá 1. janúar 2003 til 15. apríl 2018. Hver frétt var fyrst greind eftir: 1) hver sendir inn frétt; 2) hvenær er frétt birt; 3) til hvers félags beinist frétt og 4) hvert er innihald fréttar. Eftirfarandi lykil-hugtök voru notuð sem pemu í rannsókninni til pess að greina á milli innihalds frétta:

- Starfskjör par sem fjallað er um starfskjarastefnu félags.

- Stjórnarlaun par sem fjallað er um póknun stjórnar.

- Endurkaup hluta pegar tilkynnt er um væntanleg endurkaup hlutabréfa félags.

- Arðgreiðslur og aðrar tegundir ábata hluthafa af hlutabréfaeign sinni.

- Tilnefningarnefndir vegna tilurðar slíkra nefnda, stefnur peirra og starfshátta.

- Endurskoðendur par sem fjallað er um störf peirra og breytingu á peim.

- Hluthafafundir pegar hluthafi óskar eftir hluthafafundi.

- Yfirtökur pegar hluthafi óskar eftir að ræða málefni yfirtöku.

- Kosning pegar hluthafi óskar eftir kosningu á hluthafafundi.

Gögnin voru greind með tíðnitalningu ásamt eftirfarandi atriðum:

1. Fjölda tillagna á hverju ári (til pess að leita eftir próun (trend).

2. Fjölda tillagna fyrir hvert skráð félag.

3. Greiningu á lykil hugtökum til pess að sjá hvaða málefni ber hæst hjá hluthöfum.

4. Mati á pað hvort hluthafi flytji fleiri tillögur en aðrir og tegund tillagna.

Mögulegar takmarkanir eru pær að ekki eru allar fréttir skráðar í kauphöll. Sumar birtast á heimasíðu fjárfestis og stundum í fjölmiðlum. Erfitt er að koma böndum yfir slíkar birtingarmyndir, pannig tekur rannsóknin eingöngu yfir fréttir sem kauphöll skráir. Í ljósi pess mikla fjölda frétta sem greindur var og skráður, gæti höfundum hafa yfirsést einhverjar fréttir. Farið var yfir 50.000 fréttir til að finna tilfelli sem pörfnuðust nánari skoðunar og voru 2.000 af peim (fréttum úr fréttakerfi kauphallarinnar) greindar sérstaklega. Annar höfunda starfar innan eftirlitsstarfsemi með fjármálafyrirtækjum á Íslandi og hefur pekkingu meðal annars á samskiptum fjárfesta við kauphöll og eftirlitsaðila. Hinn er fræðimaður á sviði stjórnarhátta.

\section{Niðurstöður}

Niðurstöður eru birtar með peim hætti að fyrst er greining viðtalanna kynnt og pá er greint frá niðurstöðum efnisgreiningar úr fréttaveitu NASDAQ OMX á Íslandi. Niðurstöðurnar varpa ljósi á pað með hvaða hætti íslenskir fjárfestar eiga samskipti við félög sem peir fjárfesta í.

\subsection{Viðmælendur úr hópi fjárfesta}

Viðmælendur hvort sem peir komu úr röðum fjárfesta eða skráðra félaga lýstu með svipuðum hætti hvernig samskipti peirra á milli eiga sér stað og hafa próast. Fjölgun fag- 
fjárfesta hefur haft áhrif í pá átt að frumkvæði peirra til samskipta hefur aukist. Fyrst og fremst hefur peim pætti sem hefur með eftirlitshlutverk fjárfesta að gera aukist. Pessu er lýst hér á eftir en lykil pemu kynnt í fræðilegri umfjöllun stýra skipulagi umfjöllunarinnar.

\subsubsection{Stjórnarhættir og hluthafastefna}

Раð var fljótlega eftir 2008 sem fagfjárfestar fóru að setja sér hluthafastefnu. Sumir peirra höfðu áður haft leiðarljós í fjárfestingum, eins og einn stjórnarmaður lífeyrissjóðs orðaði pað:

Við vorum ekki með sjálfstæða hluthafastefnu heldur leiðbeiningar eða áherslur sem var að finna í fjárfestingarstefnu okkar og við unnum síðan fjárfestingaráætlun og pættir í henni var að finna í hluthafasamkomulagi okkar. Eiginleg hluthafastefna var takmörkuð og tók fyrst og fremst til pess hvort sjóðurinn ætlaði að vera virkur eða óvirkur hluthafi (viðmælandi 1).

Lífeyrissjóðurinn Gildi og Stefnir gáfu út hluthafastefnu árið 2013 og fylgdu pá margir fagfjárfestar í kjölfarið. Einn viðmælandi orðaði pað pannig:

Fyrir ekki svo mörgum árum hófu lífeyrissjóðirnir að birta hluthafastefnu. Félagið [sem viðmælandi er stjórnarmaður í] hefur alltaf lagt mikla áherslu á góða stjórnarhætti, pannig að taka á móti hluthafastefnu var ekki ípyngjandi. Við [stjórnin] höfum reglulega farið yfir hluthafastefnuna og fremur fengið kynningar frá fjárfestum (viðmælandi 8).

Alpýðusamband Íslands (ASÍ) talaði mjög fyrir hluthafastefnu í kjölfarið á útgáfu skýrslu um starfshætti og fjárfestingar lífeyrissjóðanna fyrir árið 2008. Breytt eignarhald í skráðum félögum á Íslandi i kjölfar hrunsins hafði enn fremur áhrif á viðhorf til stjórnarhátta og pá hluthafastefnu:

Hlutir [í skráðum félögum] eru í minna og minna mæli í beinu eignarhaldi en í meira mæli stjórnað af umboðsaðilum; lífeyrissjóðum, tryggingarfélögum og öðrum sjóðum. Við erum pátttakendur í pessari próun par sem ESG hugtakið er fyrirferðarmikið og hjá flestum hófst áherslan á G [stjórnarhætti] (viðmælandi 1).

Pessi próun hefur leitt til breytinga á stjórnarháttum fagfjárfesta, sem starfa í umboði annarra (sjóðsfélaga). Áherslan hefur verið á orðspor og endurheimt trausts, eins og einn viðmælandi orðar pað:

Eignir lífeyrissjóðanna minnkuðu mikið og pað var nauðsynlegt að finna punktstöðu og byrja frá grunni með áherslu á traust. En við veltum auðvitað fyrir okkur hvernig best væri að endurheimta traust. Óttinn var sá að aðeins væri verið að tikka í box með nýrri áherslu á góða stjórnarhætti, en með pví að sampykkja hluthafastefnu var tryggt að svo væri ekki. En petta var mjög stórt verkefni og ekki einfalt (viðmælandi 1).

\subsubsection{Samskipti milli fagfjárfesta og skráđra félaga.}

Раð kemur í ljós að samskipti milli fjárfesta og skráðra félaga geta verið vandasöm. Stundum fara pau úrskeiðis og lenda á forsíðum dagblaða en oftast eru pau hljóðlát enda í sátt og fyrir hag félaganna. Petta einkenni finnst á Íslandi rétt eins og annars staðar og er vel lýst í fræðilega hluta greinarinnar að ofan (sjá t.d. McCahery o.fl., 2016). Viðmælandi hér upplifir рað sama: 
Hefðbundið koma breytingar á hluthafastefnu á borð stjórnarinnar löngu áður en á að innleiða pær. Oftast á sér stað óformlegt samtal milli stjórnarformanns og pess fjárfestis sem hyggur á breytingar. Stjórnarformaðurinn veit pví hvað er í vændum og kynnir pað fyrir stjórninni (viðmælandi 5).

Раð var sammerkt með viðmælendum að samskipti milli fjárfesta og félags væru helst í gegnum formann stjórnar, stundum varaformanns en sjaldnar forstjóra.

Í dag eru samskiptunum beint til formanns stjórnar og stundum forstjóra. Pannig starfa lífeyrissjóðirnir sem eiga í okkur. Við erum sáttir við pað fyrirkomulag. Við erum sáttir við pað vegna pess að pað hefur pýtt að hagsmunir félagsins eru í fyrirrúmi en ekki kannski einstakra stjórnarmanna (viðmælandi 2).

Algengt er að fjárfestar fundi með félagi í aðdraganda aðalfunda, og virðast pað vera einu fundirnir á milli pessara aðila innan ársins, nema eitthvað sérstakt komi til. Á slíkum fundum er helst verið að ræða um stjórnarhætti, mun síður rekstrarleg mál.

Skráđu félögin vilja gjarnan funda með hluthöfum sínum áður en kemur að aðalfundum. Venjulega er ekki verið að fara í gegnum rekstrarleg mál pví pað gerist í kjölfarið á hverju uppgjöri, á uppgjörsfundum. Fundirnir eru meira til pess að fara yfir hvernig stjórnarhættir eru stundaðir, um starf sjórnar og hver sé stefnan til næstu ára og hvort stjórnin sé rétt saman sett til að fylgja eftir peirri stefnu. Enn fremur er rætt um samskipti stjórnar við forstjóra, upplýsingar sem stjórn fær um reksturinn og slíkt. Peim fer fjölgandi spurningunum um sjálfsmat stjórnar, hver niðurstaða slíks mats er og hvernig unnið er með рað. Раð hefur verið vaxandi áhugi á pví að skilja hvort stjórn sé rétt sett saman og hvort pað vanti pekkingu eða hæfni í stjórnina. Petta er nokkuð nýtt (viðmælandi 1).

Breyting sem tekið er eftir, er að félögin sjálf eru farin að hafa frumkvæði að fundum eins og lýst er hér að ofan.

Félögin hafa mörg haft frumkvæði að fundum með fjárfestum par sem til umfjöllunar eru málefni hluthafanna og sérstaklega pað sem hefur með stjórnarhætti að gera (viðmælandi 4).

Ýmis mál geta komið upp sem ýta á að ákveðið er að festa í form samskipti milli félaga og fjárfesta. Viðmælandi tók dæmi um pað sem hann lýsti sem erfiðleikum í samskiptum við stjórn tryggingarfélags og pað hafi leitt til endurskoðunar á samskiptum sjóðsins og stjórnir almennt:

Við hófum pá að skilgreina hvernig samskipti við í stjórn sjóðsins ættum að eiga ekki aðeins við stjórn pessa tryggingarfélags heldur enn fremur aðrar stjórnir sem við erum fjárfestar í (viðmælandi 3).

Sami viðmælandi ítrekar hversu mikilvægt pað er að pað sem kosið hefur verið um haldi og að fjárfestir láti ekki teyma sig í umræður um pað sem búið er að taka ákvörðun um og á að vera í framkvæmd:

Pað koma upp tilfelli par sem stjórnarmenn reyna að hafa áhrif á hluti sem einhugur á að vera um. Hluhafar verða að vera fastir fyrir og ef peim sýnist mál vera að fara úr böndunum, að kalla til hluthafafundar (viðmælandi 3). 
Fjárfestar og félög virðast vera að ná samskiptum almennt í góðan faglegan farveg. Dæmum um afbrigðileg samskipti hafi fækkað:

Ég tel okkur vera á góðri leið og samskiptin eru að finna sér nokkurs konar jafnvægi. Hluthafastefna er að verða algeng og allir leikendur, hvort sem peir koma frá fjárfestum eða félögum sem peir fjárfesta í, eru farnir að starfa samkvæmt slíkri stefnu (viðmælandi 3).

\subsubsection{Val á stjórnarmönnum}

Umræða um val á stjórnarmönnum skráðra félaga á Íslandi hefur verið fyrirferðarmikil seinasta hálfa annan áratuginn. Fyrir fjármálahrunið tilnefndu lífeyrissjóðirnir sína fulltrúa í stjórnir félaga og pað hélst áfram eftir hrun eða eins og einn viðmælandi orðar pað:

Pessir fulltrúar fjárfestanna voru augljóslega pað, fulltrúar fjárfestanna. Peir upplýstu viðkomandi fjárfesti um pað sem fór fram innan félagsins par sem peir voru stjórnarmenn og og samskiptin fóru fram fyrir milligöngu viðkomandi stjórnarmanns (viðmælandi 2).

Heitar umræður hafa orðið um petta og kom glöggt fram pegar á forsíður blaðanna birtist frétt um pað að formaður eins stærsta lífeyrissjóðsins væri stjórnarmaður í nokkrum skráðum félögum, par sem hann var sjálfur fjárfestir. Umræðan um val á stjórnarmönnum komst í hámæli:

Раð er ljóst að pessi lífeyrissjóður sérstaklega hefur haft aðra stefnu en hinir lífeyrissjóðirnir pegar kemur að pví að tilnefna einstakling til setu í stjórnum fyrir hönd sjóðsins. En petta olli augljósum vandkvæðum og í dag hafa peir skil parna á milli. Stjórnarmenn lífeyrissjóðsins sitja ekki í stjórnum peirra félaga sem sjóðurinn fjárfestir í (viðmælandi 4).

Skoðanir eru skiptar um með hvaða hætti lífeyrissjóðir eiga að tilnefna í stjórnir félaga sem peir fjárfesta í eða hvort peir eigi í raun ekki að gera pað. Einn viðmælandi var ákveðinn í pví að sjóðirnir purfi að fylgja stíft eftir fjárfestingum sínum, pað væri skylda peirra:

Væri pað ekki óábyrgt af fjárfesti stórrar fjárfestingar að vera ekki virkur? Í pví ljósi parf fjárfestirinn að hafa áhrif á pað hver situr í stjórn (viðmælandi 6).

Flestir viðmælandur innan raða stofnanafjárfesta voru pó á pví að pað pyrfti að stíga varlega til jarðar hvað tengingu milli fjárfestis og stjórnarmanns varðar. Allir töluðu peir um að kosning til stjórnar á hluthafafundi væri leiðin til að hafa áhrif. Ekki margir fjárfestar hafa vogarafl til pess að tilnefna stjórnarmann. Peir myndu pví purfa að vinna saman.

Venjulega er pað samtal milli stjórnarformanns og fjárfestis í undanfara aðalfunda par sem í ljós kemur væntanleg breyting á samsetningu stjórnar vegna brotthvarfs stjórnarmanns. Oft hefur stjórnarmaðurinn skoðun á pví hvað vantar inn í stjórnina til pess að pétta hana sem teymi og er jafnvel með kandidat á hliðarlínunni (viðmælandi 7).

Viðmælandinn talar um nýlega tilkomnar tilnefningarnefndir sem skýran farveg til að styðjast við í aðdraganda stjórnarkjörs. Á mörgum aðalfundum vorið 2018 urðu tilnefningarnefndir reyndin í valferli við val á stjórnarmönnum. Рað voru tveir aðilar sem höfðu prýst á petta fyrirkomulag, Eaton Vance og Gildi. Раð hefur verið áframhaldandi umræða um hlutverk og starf tilnefningarnefnda. Einn viðmælandi segir: 
Ég er fylgjandi tilnefningarnefndum. En pað á eftir að finna formið sem best hentar íslenskum aðstæðum par sem mjög fáir fjárfestar eru verulega stórir og geta klárlega haft mikil áhrif á pað hverjir setjast í stjórnir félaga (viðmælandi 5).

\subsubsection{Brotthvarf fjárfestis eða hótun par um}

Rannsóknir á pessu sviði tala um „rödd fjárfestis“ og að „,kjósa með fótunum“, pað er að segja að selja hlut sinn (McCharey o.fl., 2016). Slík dæmi er að finna á Íslandi. Ekki fyrir löngu flaggaði lífeyrissjóður pví að hann myndi selja sinn 10\% hlut í tryggingarfélagi ef stjórnarhættir breyttust ekki til batnaðar. Parna voru samskipti notuð til pess að prýsta á um breytingar. Annar lífeyrissjóður seldi einfaldlega hlut sinn án pess að tilkynna um pað fyrirfram eða nýta pað sem prýsting á breytingar. Forstöðumenn pess sjóðs voru spurðir út í pað í kjölfarið, hvers vegna sjóðurinn hafi selt og var svarið slakir stjórnarhættir. Viðmælandi frá sjóðnum skýrði frá pví að peir (stjórn sjóðsins) ræddu reglulega fjárfestingar sínar og hvort ætti að bæta í pær, minnka eða selja og pað vildu peir gera án pessa greina frá pví og alls ekki fara fram með hótanir.

Nei, við myndum aldrei hóta pví að selja. Við myndum einfaldlega selja hlut okkar, en aldrei hóta (viðmælandi 5).

Enn fremur:

Við höfum ekki gagnrýnt félag með opinberum hætti, pað er ekki hvernig við störfum. Við myndm frekar selja hlut okkar til pess að standa fast á viðmiðum okkar. En við myndum hafa viðrað áhyggjur okkar við viðkomandi félag (viðmælandi 1).

Annar viðmælandi taldi að formaður stjórnar (fjárfestis) myndi ræða við formann félags og viðra áhyggjur. Almennt voru viðmælandur sammála um pað að samskiptin sín á milli (fjárfesta og peirra sem fjárfest er í, hafi farið batnandi á undanförnum árum og orðið faglegri, meðal annars fyrir meiri formestu í samskiptum. Hluthafastefnan í dag er ítarlegri og skýrari en áður að mati viðmælenda og voru margir sammála um að í raun hafi hún próast í samvinnu fjárfesta og félaga. Samskiptin eiga sér nánast undantekningarlaust stað milli formanns stjórnar og fjárfesta, stundum forstjóra en aldrei almennra stjórnarmanna. Reglur og viðmið sem skráðu félögin hafa sett sér eru ráðandi hvað varðar form samskipta við fjárfesta.

\subsection{Efnisgreining}

Áhugaverðar niðurstöður koma fram pegar fréttir um félög skráð í NASDAQ OMX Iceland eru skoðaðar. Í ljós kemur að fjöldi frétta og tillagna virðist hafa verið lágur á árunum fyrir fjármálahrunið 2008. Flestar kom pær fram á árunum eftir 2008 og pá sérstaklega á árunum 2015, 2016 og 2018.

Tafla 1. Fjöldi frétta og tillagna á ári

\begin{tabular}{lccccccccc}
\hline & 2003 & 2009 & 2010 & 2013 & 2015 & 2016 & 2017 & 2018 & Samtals \\
\hline Fréttir & 3 & 2 & 1 & 1 & 10 & 6 & 2 & 18 & 43 \\
Tillögur & 3 & 2 & 1 & 1 & 14 & 9 & 2 & 19 & 51 \\
\hline
\end{tabular}

Tafla 1 sýnir í fyrri línu fjölda skráðra frétta í fréttaveitu kauphallar en sú seinni tillögur. Mikilvægt er að hafa í huga að taflan undanskilur árin 2004 til 2008 pegar engar tillögur birtust. Pað í sjálfu sér er merkileg niðurstaða. Á petta var bent í Rannsóknarskýrslu al- 
pingis sem kom út 2010. Par var gagnrýnt að lífeyrissjóðirnir væru ekki nógu virkir fjárfestar (Páll Hreinsson, Tryggvi Gunnarsson og Sigríður Benediktsdóttir, 2010). Pær niðurstöður eru sambærilegar mörgum öðrum rannsóknun, að stjórnarhættir voru ekki í hávegum hafðir fyrir 2008, en athyglin beindist að peim í kjölfarið (sjá til dæmis grein A. Stachowicz-Stanusch og W. Amann, 2012).

\subsubsection{Fagfjárfestar og tillögur}

Sá fagfjárfestir sem hefur sent frá sér flestar tillögur til félags sem fjárfest er í er lífeyrissjóðurinn Gildi. Pað er á árinu 2015 sem Gildi uppæærir hluthafastefnu sína og hefur eftir раð verið mjög virkur fagfjárfestir. Tafla 2 sýnir að Gildi er afgerandi og Eaton Vance Management fylgir á eftir.

Tafla 2. Fjárfestar með flestar tillögur.

\begin{tabular}{lc}
\hline Fjárfestir & Fjöldi tillagna \\
\hline Gildi & 25 \\
Eaton Vance Management & 6 \\
Ópekktir & 5 \\
VR & 1 \\
Vilhjálmur Bjarnason & 1 \\
Íscap ehf & 1 \\
EFÍA & 1 \\
Brú lífeyrissjóður & 1 \\
Afl Fjárfestingarfélag & 1 \\
Samtals & 43 \\
\hline
\end{tabular}

Nokkrir málaflokkar standa upp úr pegar inntak athugasemda fjárfesta er skoðað og tafla 3 sýnir. Starfskjaramál (stjórnenda og stjórnarmanna) kemur oftast fyrir með endurkaupum hlutafjár par á eftir og svo tillögur sem varða tilnefningarnefndir. Aðrir pættir koma mun sjaldnar fyrir. Gildi er sá fagfjárfestir sem leggur fram flestar tillögur og fylgir Eaton Vance Management í kjölfarið.

Tafla 3. Fjöldi tilkynninga eftir efni

\begin{tabular}{lc}
\hline Efni & Fjöldi tilkynninga \\
\hline Starfskjaramál & 18 \\
Endurkaup hlutafjár & 14 \\
Tilnefningarnefndir & 9 \\
Yfirtökur & 2 \\
Kosningar & 2 \\
Breytingar á endurskoðendum & 1 \\
Stjórnarlaun & 1 \\
Sampykktarbreyting & 1 \\
Endurmat á eignakaupum & 1 \\
Ávöxtun hluthafa & 1 \\
Hluthafafundir & 1 \\
Samtals & 51 \\
\hline
\end{tabular}

Pað efni sem mest áberandi er tengt starfskjörum stjórnenda og stjórnarmanna. Sá málaflokkur er enda pannig að stéttarfélög hafa sterkar skoðanir á með hvaða hætti kjör stjórnenda og stjórnarmanna eru ákveðin og eru fjölmiðlar ekki síður áhugasamir (Magnús 
Halldórsson, 2018). Til mótmæla hefur komið bæði frá stéttarfélögum og fjárfestum pegar starfskjör eru til umræðu. Endurkaup hlutabréfa er pað málefni sem kemur næst oftast fyrir en pað hlýtur mun minni umfjöllun mögulega vegna pess að par ræðir oft um tæknilega útfæslu endurkaupa. Gildi lífeyrissjóður er eini fagfjárfestirinn sem hefur sent frá sér tilkynningar um endurkaup.

\section{Umræða}

Rannsóknin veitir yfirlit yfir pað með hvaða hætti íslenskir fagfjárfestar fylgja eftir fjárfestingum sínum pegar kemur að samskiptum við pau félög sem peir eru hluthafar í. Раð hefur ekki verið rannsakað áður með peim hætti sem pessi rannsókn gerir. Í megin atriðum fara samskipti fagfjárfesta og félaga fram „bakvið tjöldin“, pað er að segja ekki með opinberum hætti, rétt eins og rannsóknir erlendis hafa komist að niðurstöðu um (McCharey o.fl., 2016). Samskiptin eiga sér stað á fundum milli forsvarsmanna fagfjárfesta og formanna stjórna, en samskiptin eru að próast í pá átt að vera meira opinber. Niðurstöðurnar varpa ljósi á pað að skilningur íslenskra fagfjárfesta á hluthafastefnum sé að pær skýri með hvaða hætti samskipti milli fagfjárfesta og félags skuli vera háttað. Enn fremur að samskiptin eigi sér stað á fundum par sem umræðuefnin eru helst tengd hluthafastefnu fagfjárfestis, stefnumarkandi áherslum félags, stjórnarháttum pess og hvernig stjórnarstarfið gangi fyrir sig og hvort samsetning stjórnar sé eins og best verður á kosið. Hluthafastefna tekur enn fremur yfir mögulegar tillögur sem fagfjárfestir kann að leggja fyrir hluthafafund. Umræða um stefnumarkandi áherslur í starfsemi félags eiga sér stað en virðast ekki algengar. Daglegir rekstrarlegir pættir eru sjaldnar til umræðu. Áhugavert framhalds rannsóknarefni væri að kanna afdrif tillagna fjárfesta.

Lífeyrissjóðurinn Gildi er virkastur íslenskra fagfjárfesta opinberlega. Meira en helmingur tillagna sem greindar voru í pessari rannsókn komu frá Gildi. Voru flestar við starfskjarastefnu, endurkaup hlutafjár og tilnefningarnefndir. Раð gæti verið líklegt að sumir aðrir fagfjárfestar hafi lagt traust sitt á virkni Gildis. Ef pað reynist rétt er pað í anda niðurstaðna Huddart (1993) sem komst að peirri niðurstöðu að flestir minni fjárfestar (og reyndar nokkrir stórir) reiða sig á virkni stærstu fagfjárfestanna. Рað pýðir ekki að aðrir fjárfestar séu ekki virkir, peir eru aðeins ekki eins virkir og Gildi í pessu tilfelli. Samkvæmt niðurstöðum Davis og Kim (2007) eru óháðir fagfagfjárfestar, eins og Gildi, virkari í eftirlitshlutverki sínu sem fjárfestir en peir sem eru í eignarhaldi banka eða ríkis. Brickley o.fl. (1988) styðja pessa niðurstöðu og skýrir pað út pannig að slíkt eignarhald leysi fjárfesta undan afskiptum stjórnenda í móðurfélagi (eða mögulega ráðuneyti). Stefnir sýnir pó að petta á ekki við í öllum tilfellum par sem sjóður tilheyrir stórum banka.

Í kjölfar 2008 fjármálahrunsins hafa fjárfestar sett sér hluthafastefnur sem taka til að mynda mið af PRI skilgreiningu Sameinuðu pjóðanna. Petta ásamt háværari kröfum um meiri formfestu í samskiptum fjárfesta og félaga sem fjárfest er í, hefur almennt gert hluthafastefnu ítralegri og skýrari. Hún fór að birtast í meira mæli upp úr 2013 og í lok árs 2015 höfðu flestir fjárfestar sett sér slíka stefnu. Fagfjárfestar á Íslandi eru orðnir pað stór hluti af mengi fjárfesta, rétt eins og erlendis (Schleifer og Vishny, 1986; Kahn og Winton, 1998), аð krafan er að peir verði virkir í eftirlitshlutverki sínu. Peir hafa fylgt fordæmi erlendis frá og sett sér hluthafastefnur sem fjalla um mikilvægi langtíma hagsmuni, góðra stjórnarhátta og mikilvægi tilvistar starfskjarastefnu. Fer saman áhersla á langtíma sjónarmið og aðhald fjárfestis og er petta í takt við erlendar rannsóknir samanber Bebchuk o.fl. (2014) sem greinir frá pví að langtíma sjónarmið skili sér í ríkara aðhaldi fjárfestis.

Erlendir fjárfestar nýta sér priðja aðila til kosninga á hluthafafundum í meira mæli en gert er á Íslandi. Almennt er sterk áhersla á gagnsæi í hluthafastefnu erlendra fjárfesta. Leiðbeiningarnar frá Bretlandi sem vísað var til horfa mjög til pess að fjárfestar ættu að skýra frá pví opinberlega með hvaða hætti peir hyggjast rækja eftirlitshlutverk sitt og birta niðurstöður með hvaða hætti peir kjósa á hluthafafundum. Fáir íslenskir fjárfestar birta upplýsingar um pað hvernig peir kjósa. Stefnir fór fyrstur fram með slíkar upplýsingar. 
Síðan 2016 hefur Gildi viðhaft slíkt gagnsæi og LSR frá 2017. Lífeyrissjóður verslunarmanna ákvað í desember 2017 að greina frá pví hvernig kosið er. Рað eru dæmi um smærri fjárfesta sem viðhafa virkt aðhald en eru pó ekki mjög gagnsæir um starfsemi sína (Kristinn Hallgrímsson, 2016). Vissulega má telja pað sjónarmið að mestu máli skipti virkt eftirlit fjárfesta, svo í kjölfarið gæti gagnsæið um pað orðið meira.

Líklegt er að samskipti íslenskra fjárfesta við pau félög sem peir fjárfesta í muni halda áfram að próast og taka mið af reynslu annarra landa. Ný löggjöf í Evrópu mun hafa áhrif á Íslandi. Aukið vægi fagfjárfesta sem stærstu hluthafa flestra skráðra félaga mun enn fremur hafa áhrif. Próunin á Íslandi hefur verið í átt til aukins umfangs eftirlitshlutverks fagfjárfesta með skýrri hjarðhegðun pannig að minni aðilar hafa oft fylgt peim stærri. Hugtök eins og ESG eru ekki aðeins að ná fótfestu í starfi fjárfesta sem purfa að ná góðri ávöxtun en vilja á sama tíma hafa áhrif til góðs, heldur enn fremur meðal almennings sem setur sífellt meiri prýsting á félög um ábyrga starfsemi.

\section{Heimildir}

Amann, W. og Stachowicz-Stanusch, A. (2012). Business Ethics Following a Financial Crisis. Í Amann, W. og A. Stachowicz-Stanusch. (ritstj.) Business integrity in practice: Insights from international case studies, 193-204. London. Business Expert Press.

ASÍ. (2009). ASÍ vill strangar siðareglur um stefnu og starfssemi lífeyrissjóða. Sótt af http://www.asi.is/um-asi/utgafa/frettasafn/almennar-frettir/asi-vill-strangar-sidareglur-um-stefnu-og-starfssemi-lifeyrissjoda/.

ASÍ. (2013). Stefna Alpýđusambands Íslands í lífeyrismálum og málefnum lífeyrissjóðanna. Sótt af http://www.asi.is/ media/3176/Stefna_AS___feyrism_lum___sam_20_2_2013.pdf.

Ásdís Kristjánsdóttir. (2013). Hluthafar Íslands. Sótt af https://www.arionbanki.is/library/skrar/Greiningar/ Markadspunktar/280513_Hluthafar\%20\%C3\%8Dslands.pdf.

Ásta Dís Óladóttir, Friðrik Árni Friðriksson, Gylfi Magnússon og Valur Práinsson. (2017). Að pjóna sömu herrum en keppa pó. Sameiginlegt eignarhald á íslenskum hlutabréfamarkaði. Stjórnmál og stjórnsýsla, 13(1), 27.

Bebchuk, L. A., Brav, A. og Jiang, W. (2015). The Long-Term Effects of Hedge Fund Activism. Sótt af https://papers. ssrn.com/abstract=2291577.

Bell, J. (2014). Doing Your Research Project: A Guide for First-Time Researchers. McGraw-Hill Education (UK).

Bharath, S. T., Jayraman, S. og Nagar, V. (2013). Exit as Governance: An Empirical Analysis. The Journal of Finance, 68(6), 2515-2547.

Bourgeault, I., Dingwall, R., og Vries, R. de. (2010). The SAGE Handbook of Qualitative Methods in Health Research. SAGE.

Brickley, J. A., Lease, R. C., og Smith, C. W. (1988). Ownership structure and voting on antitakeover amendments. Journal of Financial Economics, 267-291.

Carlson, M. D. (2009). Fiduciary Duty. Sótt af https://www.law.cornell.edu/wex/fiduciary_duty.

Company Law, $290 \S$ (1995). Sótt af https://www.althingi.is/lagas/nuna/1995002.html.

Company News Nasdaq. (2018) Sótt af http://www.nasdaqomxnordic.com/news/-companynews.

Corporate Governance 2.0. (2015). Sótt af https://hbr.org/2015/03/corporate-governance-2-0.

Davis, G. F., og Kim, E. H. (2007). Business ties and proxy voting by mutual funds. Journal of Financial Economics, 85(2), 552-570.

DiCicco-Bloom, B. og Crabtree, B. F. (2006). The qualitative research interview. Medical Education, 40(4), 314321.

Directive (EU) 2017/828 - EFTA. (2017). Sótt af http://www.efta.int/eea-lex/32017L0828.

Directive (EU) 2017/828 (2017). Sótt af http://eur-lex.europa.eu/legal-content/EN/TXT/HTML/?uri=CELEX:32017L0828ogfrom=EN.

Edmans, A. (2009). Blockholder Trading, Market Efficiency, and Managerial Myopia. The Journal of Finance, 64(6), 2481-2513.

ESG: Sharing stewardship. (2018). IPE. Sótt af www.ipe.com/investment/esg-sharing-stewardship/10022520. fullarticle.

Financial Reporting Council. (2012). The UK Stewardship Code. Sótt af https://www.frc.org.uk/investors/ukstewardship-code.

Fink, L. (2017). Larry Fink's letter to CEO's. Sótt af https://www.blackrock.com/corporate/en-no/investor-relations/larry-fink-ceo-letter.

Fichtner, J., Heemskerk, E., og Garcia-Bernado, J. (2017). Hidden power of the Big Three? Passive index funds, re-concentration of corporate ownership, and new financial risk. Business and Politics, (19), 298-326.

Fjármálaeftirlitið. (2017a). Ársreikningabok fjármálafyritækja 2016. Sótt af https://www.fme.is/media/utgefid- 
efni/Arsreikningabok-fjarmalafyrirtaekja-2016-agust.pdf.

Fjármálaeftirlitið. (2017b). Samantekt ársreikninga lífeyrissjóða 2016. Sótt af https://www.fme.is/utgefid-efni/tolulegar-upplysingar/.

Fjármálaeftirlitið. (2019). Verðbréfamarkaðurinn og fjármálastöđugleiki. Sótt af https://www.fme.is/media/utgefidefni/Verdbrefamarkadurinn-og-fjarmalastodugleiki.pdf.

Giannetti, M., og Laeven, L. (2009). Pension Reform, Ownership Structure, and Corporate Governance: Evidence from a Natural Experiment. The Review of Financial Studies, 22(10), 4091-4127.

Gildi lífeyrissjóður (2015). Fundargerð ársfundar Gildi lífeyrissjóðs. Sótt af https://gildi.is/wp-content/uploads/2017/03/Fundargerd-arsfundar-15.5.2015.pdf.

Gilian, S. L., og Starks, L. T. (2003). Corporate Governance, Corporate Ownership, and the Role of Institutional Investors: A Global Perspective. Journal of Applied Finance, 13(2), 19.

Goergen, M., Renneboog, L. og Zhang, C. (2008). Do UK Institutional Shareholders Monitor Their Investee Firms? (SSRN Scholarly Paper No. ID 1120204). Rochester, NY: Social Science Research Network.

Grossman, S. J., og Hart, O. D. (1980). Takeover Bids, the Free-Rider Problem, and the Theory of the Corporation. Bell Journal of Economics 11(1), 42.

Guidelines, reports and position papers (2018). Sótt af https://www.blackrock.com/corporate/about-us/investment-stewardship/voting-guidelines-reports-position-papers.

Gunnar Baldvinsson, Áslaug Árnadóttir og Eggert Benedikt Guðmundsson (2018). Starfshópur um hlutverk lífeyrissjóða i uppbyggingu atvinnulifs. Sótt af https://www.stjornarradid.is/lisalib/getfile.aspx?itemid=cee149c2-0019-11e8-9423-005056bc4d74.

Gylfi Magnússon (2007). Markaður verður til: Saga íslenska hlutabréfamarkaðarins Hagfræðistofnun Háskóla Íslands. Sótt af http://www.ioes.hi.is/sites/hhi.hi.is/files/R-series/2007/R0701.pdf.

Gylfi Magnússon (2016). Lárétt eignarhald. Vísbending, 20,1-4.

Hewitt, P. (2011). The exercise of shareholder rights (OECD Corporate Governance Working Papers No. 3) (p. 43). Paris: OECD Publishing.

Hirschman, A. (1970). Exit, Voice and Loyalty: Responses to Decline in Firms, Organization and Sates. Cambrigdge, MA: Harvard University Press.

Hrafn Bragason, Héðinn Eyjólfsson og Guðmundur Heiðar Frímannsson (2012). Úttekt á fjárfestingarstefnu, ákvarðanatöku og lagalegu umhverfi lífeyrissjóðanna i aðdraganda bankahrunsins 2008. Sótt af https://www.lifeyrismal.is/is/frettir/uttekt-a-fjarfestingarstefnu-akvardanatoku-og-lagalegu-umhverfi-lifeyrissjodanna-iaddraganda-bankahrunsins-2008.

Huddart, S. (1993). The Effect of a Large Shareholder on Corporate Value. Management Science, 39(11), 14071421.

ICSA The Governance Institute (2017). What is corporate governance? Sótt af https://www.icsa.org.uk/about-us/ policy/what-is-corporate-governance.

Institutional investors establish the first edition of a Dutch Stewardship Code (2017). Sótt af https://www. eumedion.nl/en/news/institutional-investors-establish-the-first-edition-of-a-dutch-stewardship-code.

Investment Stewardship | BlackRock. (n.d.). Sótt af https://www.blackrock.com/corporate/en-gb/about-us/ investment-stewardship.

Isaksson, M., og Celik, S. (2013). Who cares? Corporate Governance in today's equity markets Working paper No. 8 (p. 581). Paris: OECD.

Jón G. Hauksson. (1995). Að vera eða vera ekki? Sótt af http://timarit.is/view_page_init.jsp?pageId=3176560.

Kahn, C., og Winton, A. (1998). Ownership Structure, Speculation, and Shareholder Intervention. The Journal of Finance, 53(1), 99-129.

Kristinn Hallgrímsson (2016). Fundargerð aðalfundar Reita fasteignafélags hf. 2016. Sótt af https://www.reitir.is/ static/files/Adalfundir/2016-Adalfundur/10fundargerd-adalfundar-reita-2016.pdf.

La Porta, R., Lopez-de-Silanes, F., Shleifer, A., og Vishny, R. (2000). Investor protection and corporate governance. Journal of Financial Economics, 58(1), 3-27.

Lífeyrissjóðir sýni félagslega ábyrgð. (2006). Sótt af http://www.visir.is/g/2006108080038.

Lífeyrissjóður starfsamanna ríkisins. (2017). Hluthafastefna Lífeyrissjóðs starfsmanna ríkisins. Sótt af https://www. lsr.is/media/log-og-samthykktir/Hluthafastefna-februar-2017.pdf.

Magnús Halldórsson. (2017). Markaðir upp, krónan styrkist og erlendir fjárfestar létu sjá sig. Sótt af https://kjarninn. is/skyring/2017-03-14-markadir-upp-kronan-styrkist-og-erlendir-fjarfestar-letu-sja-sig/.

Magnús Halldórsson. (2018). Stjórn N1: Okkur er fullljóst að launin eru mjög góð. Sótt af https://kjarninn.is/frettir/ 2018-03-19-stjorn-n1-okkur-er-fullljost-ad-launin-eru-mjog-god/.

Már Guðmundsson. (2000). Íslenska lífeyriskerfið. Sótt af http://www.asi.is/media/3184/_sl.1_feyriskerfi___M_r_Gu_mundss.2000.pdf.

McCahery, J. A., Sautner, Z., og Starks, L. T. (2016). Behind the Scenes: The Corporate Governance Preferences of Institutional Investors. The Journal of Finance, 71(6), 2905-2932.

Morgunblaðið. (2018). Eaton Vance óskar eftir tilnefningarnefndum. Sótt af http://arc.ci.x-cago.net/data/ mbl/20180308/pages/01090/articles/MBL-20180308-01090001.pdf.

OECD. (2009). Corporate Governance and the Financial Crisis: Key Findings and Main Messages. OECD Publishing. Sótt af http://www.oecd.org/daf/ca/corporategovernanceprinciples/43056196.pdf. 
OECD. (2011). The Role of Institutional Investors in Promoting Good Corporate Governance, Corporate Governance (No. 978-92-64-12875- 0) (p. 139). Paris: OECD Publishing.

OECD. (2015). G20/OECD Principles of Corporate Governance Principles. Paris: OECD Publishing. Sótt af http:// dx.doi.org/10.1787/9789264236882-en.

OECD. (2017). Responsible business conduct for institutional investors. Sótt af https://mneguidelines.oecd.org/ RBC-for-Institutional-Investors.pdf.

Páll Hreinsson, Tryggvi Gunnarsson og Sigríður Benediktsdóttir. (2010). Report of the Special Investigation Commision. Alpingi. Sótt af https://www.rna.is/eldri-nefndir/addragandi-og-orsakir-falls-islensku-bankanna-2008/skyrsla-nefndarinnar/english/.

Ragnhildur Helgadóttir. (2013). Stjórnskipunin og meðferð á fé lífeyrissjóða. Stjórnmál og stjórnsýsla, 9(1), 191210.

Schleifer, A., og Vishny, R. W. (1986). Large Shareholders and Corporate Control. Journal of Political Economy, 94(3), 461-488.

Schwartzkopff, F. (2017). The \$1 Trillion Guide to Nordic Banking. Sótt af https://www.bloomberg.com/news/ articles/2017-05-01/a-1-trillion-asset-management-boom-is-a-guide-to-nordic-banking.

SEC. (2010). Concept Release on the U.S. Proxy System. Sótt af https://www.sec.gov/rules/concept/2010/34-62495. pdf.

Seðlabanki Íslands. (2018). Eignir lífeyrissjóða. Reykjavík.

Shleifer, A., og Vishny, R. W. (1997). A Survey of Corporate Governance. The Journal of Finance, 52(2), 737-783.

Sigurður Jóhannesson. (2017). Umsvif lífeyrissjoða í íslensku hagkerfi (No. C17:07). Hagfræðistofnun Háskóla Íslands.

Sjöstrand, S.E., Berglund, T., Grönberg, L., Kallifatides, M., Poulfelt, F., Pöyry, S. Og Sigurjonsson, T.H. (2016). Nordic Corporate Governance : An Extensive In-Depth Study of Corporate Governance and Board Practices in 36 Large Companies. Stockholm School of Economics Institute for Research, 175 p.

Stefán Árni Pálsson. (2015). Ný hluthafastefna Gildis-lífeyrissjóðs. Sótt af http://www.visir.is/g/2015150129939.

Sunna Ósk Logadóttir. (2007). Horft til mannréttinda og umhverfismála. Sótt af https://www.mbl.is/greinasafn/ grein/1125409/.

Van der Elst, C., og Aslan, G. (2009). The Economic Consequences of Large Shareholder Activism. Sótt af http:// www.europarl.europa.eu/thinktank/en/document.html?reference=IPOL-ECON_ET(2009)416245.

Vanguard's approach to investment stewardship. (2017). Sótt af https://about.vanguard.com/investmentstewardship/.

Walker, D. (2009). A review of corporate governance in UK banks and other financial industry entities. Sótt af http:// webarchive.nationalarchives.gov.uk/+/http://www.hm-treasury.gov.uk/walker_review_information.htm.

Wong, S. (2015). Is institutional investor stewardship still elusive? Sótt af https://papers.ssrn.com/sol3/papers. cfm?abstract_id=2654229.

Pröstur Olaf Sigurjónsson, Thomas Poulsen og Guðrún Erla Jónsdóttir. (2019). Ownership Strategy: A New Governance Mechanism for Collective Action and Responsible Ownership. 19th European Academy of Management Conference 2019. 
